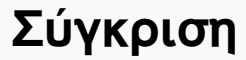

Tóp. 21 (2010)

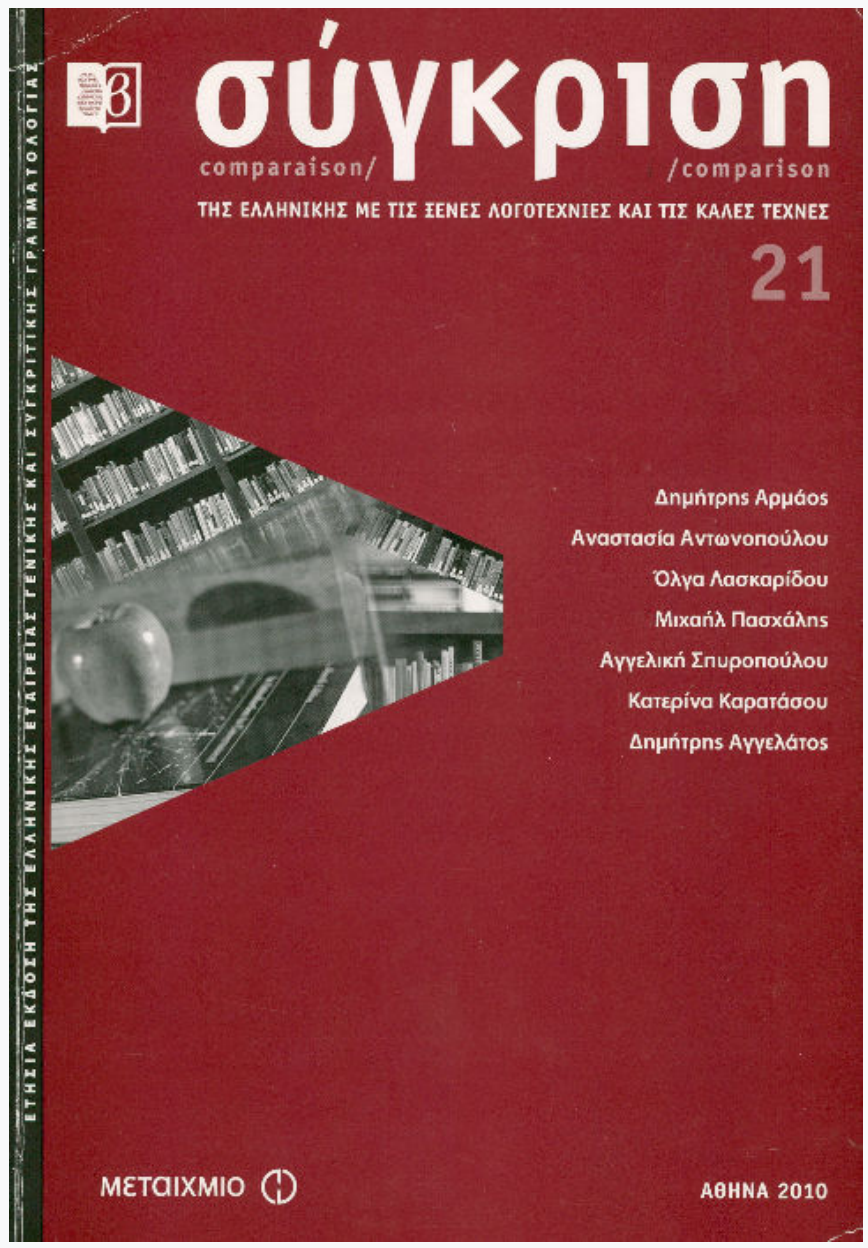

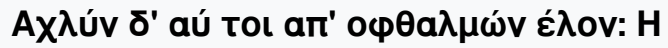

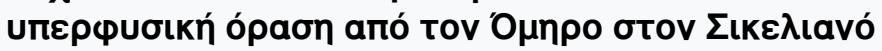

Michael Paschalis

doi: $10.12681 /$ comparison.86

Copyright (C) 2017

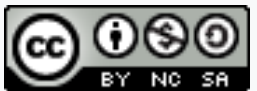

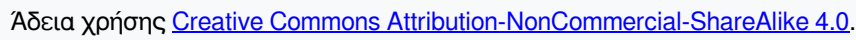

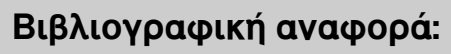

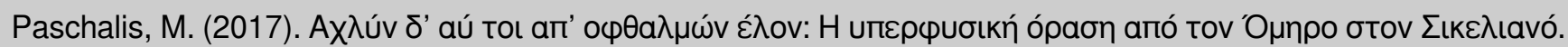

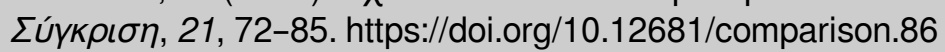




\section{"I Removed the Mist that Clouded your Eyes": Supernatural Vision from Homer to Sikelianos}

\section{Introduction: Athena and Diomedes in Iliad 5}

n Iliad 5.114-120 Diomedes prays to Athena for vengeance on Pandaros who had earlier wounded him with an arrowshot. The goddess appears and puts fresh strength in his limbs and, without noticing his prayer for vengeance, gives him aid in the fighting through an unexpected gift. She says to him:

I have removed from your eyes the mist ( $\left(\dot{x} \chi \lambda u^{\prime} v\right)$ that was before on them, so that you may distinguish gods from men. If, then, any other god comes here and offers you battle, do not fight him; but should Zeus' daughter Aphrodite come, strike her with your spear and wound her.

Taking advantage of his newly acquired superhuman vision, Diomedes kills Pandaros and wounds Aphrodite in the arm, as she is attempting to rescue her wounded son Aeneas from his hands. He then charges three times unsuccessfully against Apollo, in order to kill Aeneas now shielded by the god in a dark cloud. Finally with the aid of Athena Diomedes wounds none other than the god of war himself, Ares, who withdraws from the battlefield in great pain (133-863).

The Homeric episode has puzzled scholiasts and readers for a number of reasons: the presence on human eyes of $\alpha \chi \lambda$ ú or special disability that prevents them from seeing the gods is unparalleled in the Homeric epics; Diomedes later tells Athena that he followed her instructions not to fight any other god but Aphrodite (815-824), which of course is untrue; in the next book Diomedes appears reluctant to fight the gods, displaying realization of his human limits and fear of what happened to Lycurgus, a renowned theomachos. As regards the last point, it is worthy of attention that when Apollo warns Diomedes in Book 5 as the hero attempts a fourth attack against him (440-442: "Take heed, son of Tydeus, and draw off; think not to match yourself against gods, for men that walk the earth cannot hold their own with the immortals"), the Achaean hero desists but shows neither realization of his human condition nor fear of the god; he is only careful to avoid the god's wrath.'

Although there is no clear morale with regard to human limits to be drawn from the aristeia of Diomedes, the removal of $\dot{\alpha} x \lambda \dot{v} \varsigma$ from his eyes, which opened 
a new, supernatural horizon to human vision, exercised a tremendous fascination on the imagination of Homer's readers from antiquity to the 20 th century. It was reinterpreted by pagan and Christian writers in various philosophical, allegorical and literary contexts. Below I will be concerned with instances of its reception and re-staging on pivotal moments of historical and intellectual development. The scenes from Virgil and Korais draw directly on Homer while Boethius' Consolation involves also Virgilian mediation. The figure of alafroiskiotos, best known from Solomos and Sikelianos, has been viewed as a distant relation of the Homeric Diomedes and Virgilian Aeneas. I have added a discussion of Solomos' blind Homer because of the importance of the blind visionary in pre-romantic and romantic period. Supernatural vision, the "light-shadowed" poet, and blind Homer merge in Sikelianos' "Alafroiskiotos".

\section{Venus and Aeneas}

Some eight-hundred years after Homer we meet again Aeneas and Venus (Aphrodite), this time in the burning Troy of Virgil's Aeneid 2. The Trojan hero has just witnessed from the roof of the royal palace the slaughter of King Priam by Neoptolemus, son of Achilles. He now catches sight of Spartan Helen hiding from the wrath of the Achaeans; his anger flares up, he delivers an indignant monologue, and is about to extract his sword and exact vengeance for the misfortunes of his city. Suddenly his divine mother appears before him, lighting the darkness with pure radiance. She stops his hand as once Athena had stopped the threatening hand of Achilles in the hero's clash with Agamemnon; then she rebukes him for having lost his self-control, reminds him of his duty towards his family that are in grave risk and reveals to him that neither Helen nor Paris are to blame for the destruction of Troy but the gods themselves. She then removes the mist (nubem) that "veils and dulls mortal vision" and offers him an apocalyptic vision of Neptune, Juno and Minerva destroying the city. After urging him to flee from the site and ultimately from Troy, Venus vanishes into the dense shadows of the night (559-633).

Homeric Diomedes was punished during his nostos for wounding Aphrodite and later in the Aeneid Virgilian Diomedes appears repentant of his action and converted to the cause of Aeneas and Rome. ${ }^{2}$ But other more dramatic changes have occurred since the construction of the Homeric scene with Diomedes and Athena. These involve human distance from the gods, Roman historical consciousness and the altered nature of heroism. Drawing a sword against the 
gods destroying Troy would have been unthinkable for Aeneas: the hero cannot even embrace his own mother, despite his ardent desire to do so (Aen. 1.4071.409). Besides, it would have been pointless to attack deities that have no truly physical presence and who could very well be mere manifestations of the progress of history at work. The historical horizon of the Aeneid is vast, reaching as far ahead as Augustan Rome, and historical consciousness is immensely important. In Aeneas' famous encounter with Helen (sometimes wrongly considered inauthentic) ${ }^{3}$ and the witnessing of Priam's death Aeneas relives the beginning and the end of the Trojan war. The apocalyptic vision provides the ultimate confirmation of Troy's end, with Neptune destroying the walls of the city he himself once built, and also points the road to a new beginning, the road to exile, to Italy and eventually to Rome. Aeneas does not personally perform any act of heroism on the battlefield in the narrative of the fall of Troy: at this stage duty to his family and to the future of his people and his descendants take precedence over battle heroism. This momentary vision of light amid the flaming darkness consuming the past places upon Aeneas the burden of a historical mission never before or after shouldered by an ancient epic hero.

\section{Lady Philosophy and Boethius}

Between 524 and 526 A.D. the philosopher and politician Anicius Manlius Severinus Boethius, who had risen to power under the favor of the Ostrogothic King of Italy Theodoric the Great, was found guilty of treason, was imprisoned and brutally executed. ${ }^{4}$ During his imprisonment Boethius wrote his famous treatise The Consolation of Philosophy (De philosophiae consolatione). He has been considered as the last writer and thinker of Latin antiquity and the first of the Medieval period. Dante assigned Boethius a place in his Paradise and the Consolation proved a vastly influential and popular work until the Renaissance and even later. ${ }^{5}$

The Consolation, a work in prosimetric form frequently classified as Menippean satire, ${ }^{6}$ begins with pathetic elegiac verses inspired to the poet by the Muses. In these the aged and ill narrator laments in tears his dramatically changed fortune. Suddenly an awe-inspiring female figure appears before him. She angrily denounces the Muses, calling them "whores of the stage" and "Sirens" who instill sweet poison in the veins of a man nurtured with the teachings of ancient philosophy, and dismisses them. The eyes of the narrator are clouded with tears and so he cannot recognize the woman. With a fold of her 
dress she wipes the tears from his eyes, removing the mist (nube) of mortal affairs that clouds them. The narrator absorbs the sparkling sunlight and thus retrieves his former clear vision, and in the female figure he recognizes the woman who nursed and brought him up, Lady Philosophy (1.1-3). In the dialogues of the five books of the Consolation Philosophy consoles Boethius by explaining the fickleness of Fortune and hence the transitory nature of earthly belongings (wealth, honors and power, and fame) and outlines the nature of the true good which is God, and of divine providence that governs the world without precluding human free will.

At the time when the sun of antiquity is sinking, Philosophy enters the dark prison of Boethius and renews for the last time the role of Homeric Athena and Virgilian Venus in guiding her favorite hero. She removes the mist of worldly values from his eyes, turns his gaze upwards and opens up his vision to a providentially governed world where all is for the best, goodness is a reward to itself and suffering from evil is seen as a virtue. At the threshold of the Middle Ages the persecuted philosopher transforms his prison cell into a fortress of sapientia. This is not, however, the fortress of a Christian martyr and saint, but of a pagan, persecuted philosopher, another Socrates or Seneca. Boethius was Christian but for consolation he turned not to Christian but to pagan philosophy. The fortress of sapientia performs the double function of spiritual preparation for the centuries to come and of preserving ancient knowledge. It was through Boethius that much of the thought of the Classical period was made available to the Western Medieval world. As for the re-enactment of the longstanding dispute between poetry and philosophy, Lady Philosophy may appear to win the day but the battle is fought on the ground of an elaborate work of literature steeped in the traditions of classical poetry. ${ }^{7}$

\section{Korais and Solomos}

In the Eastern Medieval world literary, philosophical and scholiastic interest in Homer was never lost. But in pre-revolutionary and revolutionary Greece the poet will be rediscovered through different paths. For the world of the Enlightenment it is reason, light and true vision that matter: Korais assigns to philosophy the role of Homeric Athena and makes her the champion in this area. $^{\mathbf{8}}$ His Athena-philosophy has an earlier formal precedent in Athena-Lady Philosophy as seen in Boethius' Consolation, but the Homeric goddess is now called upon to play a completely different role, to provide reasoned and not 
supernatural vision. For the pre-romantics and the romantics it is darkness and instinctive, intuitive, inward knowledge that matter: the champions in this area are blind Homer together with Macpherson's blind Ossian, who was modeled after Homer and represents the greatest literary forgery of all times. ${ }^{9}$ In this context I discuss the figure of blind Homer in Solomos' "The Shade of Homer". Korais' Diomedes and Solomos' Homer have two striking points in common: they are initially represented as blind and then acquire metaphorical vision; their vision is made to serve the world of modernity. Despite their different itineraries and goals, the paths of Korais and Solomos converge on the common ground of the Hellenic cause. While working on The Free Besieged Solomos will later adopt the persona of alafroiskiotos or visionary. The persona has been viewed as a distant relation of the Homeric Diomedes and Virgilian Aeneas and will inspire Sikelianos' lyrical poem "Alafroiskiotos", the most exalted representation of supernatural vision which will absorb both Homeric Athena and blind Homer.

Homer and the enlightened vision. Adamantios Korais (Smyrna 1748-Paris 1833 ) is the greatest figure of the Modern Greek Enlightenment. From 1811 to 1820 he published a commentary on Homer's Iliad, books $1-4 .^{\mathbf{1 0}}$ These four volumes included respective Prolegomena, which were much later published separately and became known as O Papatrechas ("The hastily reading priest"). It is a kind of epistolary narrative in four sequels which thematizes light metaphors in the story of the "enlightenment" of an uneducated priest. As I have explained elsewhere, ${ }^{11}$ the systematic study of the narrative reveals a unique synthesis of light metaphors deriving from classical literature (Homer, Plato and others), from the Gospels and texts of the Greek Orthodox Church, and from the symbols of European Enlightenment.

At some point Papatrechas' learned friend and author of the Iliad commentary (a persona of Korais himself) refutes the attacks of the hypocritical priest Pachomios on what he claimed to be harmful modern ideas, reiterates the identification of true philosophy with the Gospels, and elaborates on the modernity of the New Testament. He then proceeds to employ a remarkable comparison that brings together pagan philosophy, Christianity and Homer's Iliad: true philosophy, he says, renews ancient wisdom and tears open "the veil

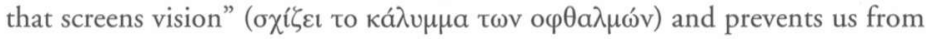
discerning our duties towards god and men, just as once the goddess Athena

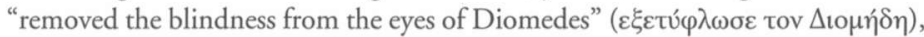
so that he could make out the gods and men on the Trojan battlefield. He then 


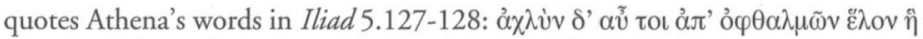

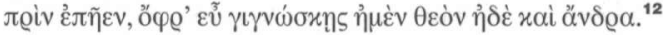

In Papatrechas the "blind" are the "uneducated", those who stand against the ideology of the Enlightenment. Laymen and especially priests and Church

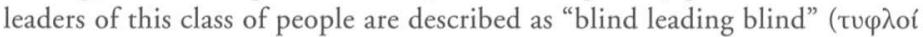

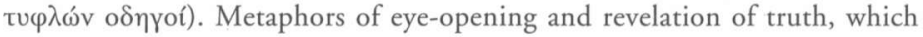
appropriate the language, metaphors and imagery of the Enlightenment, dominate the present context and the whole narrative. As if engaged in a polemic with Boethius, Korais opts for a fighting Athena-philosophy, a representative of modern reason, and assigns her the task of Hellenic revival. The publication of the fourth part of the Homeric Prolegomena, which contains the abovementioned episode, takes place in 1820, on the eve of the outbreak of the Greek War of Independence.

Blind Homer acquires vision. As noted earlier, blind Homer and blind Ossian are dominant literary figures in pre-romantic and romantic Europe. Two early compositions by young Dionysios Solomos (1798-1857), one of the founders of the literature of renascent Greece, are dedicated respectively to blind Ossian ("Ode to the moon") and blind Homer ("The Shade of Homer"). They were composed in 1821-1822, at the time of the outbreak of the Greek War of Independence and about the time Korais proposed Homer as the archetypal text for the acquisition of enlightened vision. In the so-called "Shade of Homer", Homer (he is not mentioned by name and some refer the poem to Ossian) ${ }^{13}$ appears to Solomos in a dream: it is night time and the ancient bard is lying on the shore; his clothes are old and in rags and the breeze is blowing through his white hair; he is turning his sightless eyes about the starry sky. Then he rises slowly and approaches the poet "like one who could see".

The present epiphany of Homer has a rich intertextual background going back to antiquity. ${ }^{14}$ Relevant to our earlier discussion are the bard's clothes that are old and in rags, reminding those of Boethius' Lady Philosophy. Also his blind gaze that explores the starry sky recalls Boethius' opened eyes that explored the causes of things in the sky (the Consolation reflects a wide knowledge of the heavenly bodies and Boethius is said to have written also astronomical treatises). As I. N. Perysinakis has shown ${ }^{\mathbf{1 5}}$ the chief model for "The Shade of Homer" is Petrarch's Africa 9.166-9.172 and its context. The Roman poet Ennius, aboard the ship taking Scipio the Elder back to Rome after the victory over Hannibal at Zama, recounted a dream he had had the night before the battle: Homer appeared to him and showed him in a prophetic vision young Franciscus ( $=$ Petrarch) at work on 
Africa, the epic poem that would sing Scipio's deeds (which Ennius himself had previously sung) and would win for Petrarch supreme glory. In Africa Homer is dressed in rags (9.167-9.168 quem rara tegebant / frusta toge $)^{16}$ as he is portrayed in "The Shade of Homer". Since the influence of Boethius' Consolation on Petrarch's Africa is well-documented, ${ }^{\mathbf{1 7}}$ the Petrarchan passage, which Solomos read, may have absorbed the appearance of Lady Philosophy to Boethius.

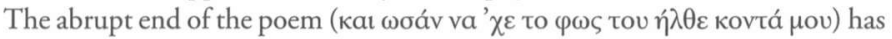
given rise to speculation as to what Homer may have said to Solomos. ${ }^{18}$ The only piece of information we possess is that, according to Iakovos Polylas, the first editor of Solomos' collected works, Homer commanded the poet to write in demotic Greek. ${ }^{19}$ The fact that Petrarchan Homer spoke to Ennius in Greek (Graio [...] more) carries little significance in light of the fact that in his speech he praised greatly a poem to be written in Latin and not in Italian. More relevant to my topic is the fact that Solomos' Homer approaches the poet "as if he were not blind”. The phrase reworks Petrach's similisque videnti and could be construed as Latinism. But there may be more meaning to it than meets the eye.

In Africa Homer's blindness offers a ghastly spectacle that horrifies Ennius. ${ }^{20}$ The Roman poet voices at length his impassioned wonder at the fact that the ancient bard is blind; he expected him to have the sight of a lynx, since he managed to show him in clear light all the beauties of Greece. Homer replies that God, who deprived him of bodily sight, gave him other eyes, with which he could see these mysteries. The treatment of the bard's blindness is very different in "The Shade of Homer". The first stanza is taken up by the mourning song of the nightingale pervading the calm night in the dim moonlight. In the next stanza Solomos makes Homer first "roll his extinguished eyes towards the many stars of the sky", then rise, and next draw near "as if he could see". Based on the information provided by Polylas one could interpret the last four lines as follows: at a pivotal time for renascent Greece Solomos' Homer turns his (sightless) gaze away from nature and the cosmos and turns his attention to the pressing issue of language. This change of priorities accompanies a shift from blindness to vision which, given the open-ended closure of the poem, may invite the reader to interpret the phrase $\omega \sigma a ́ v$ va ' $\chi \varepsilon$ to $\varphi \omega \varsigma$ tov as Homer metaphorically acquiring vision for the occasion.

There is no doubt that Solomos was attracted to the episode of Petrarch's Africa because of the emphasis poetic succession receives there: Ennius is alter Homerus and Petrarch is about to become alter Ennius. In "The Shade of Homer" young Solomos shows his poetic ambition by claiming the heritage of 
Homer, the archetypal poet of the Western world; in his Dialogos, written two years later, he will state that his only concern is liberty and (the Modern Greek) language and will cast himself in the role of Dante, the archetypal European champion of the "vulgar" language and national liberty. ${ }^{21}$

Solomos acquires the vision of an alafroiskiotos. In fr. 6 of the third draft of The Free Besieged (1844), Solomos adopts the persona of an alafroiskiotos, a "light-shadowed" figure who possesses supernatural vision. The poet exercises his vision in "a night full of wonders, a night scattered with magic". The passage culminates in the sighting of the intriguing and mysterious figure of "The Lady clad in the Moon" (Fengarondymeni) as she emerges from the placid waters of a lake when moonlight mingles with them. ${ }^{22}$ The figure of alafroiskiotos or visionary is known from Greek folk tradition as one who can see unearthly visions. In 1871 Nikolaos Politis discussed his powers in the context of folk tradition and suggested that "This belief is founded on the idea that the human eye, as if with a mist before it, is unable to distinguish supernatural objects". In order to elucidate the idea Politis adduced the examples of Homeric Athena removing the $\alpha x \lambda$ ú from the eyes of Diomedes and of Virgil's Venus removing the nubes that clouded the vision of her son Aeneas. ${ }^{23}$ There have been numerous interpretations as regards the identity of the "Fengarondymeni" ${ }^{24}$ Two things merit our attention in connection with the supernatural vision Diomedes acquires in Iliad 5: the figure which Solomos-alafroiskiotos sees is "divine", in

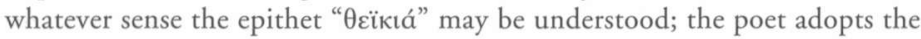
persona of an "alafroiskiotos" which grants him supernatural vision only in the third draft of The Free Besieged and for the sole purpose of seeing this divine figure emerging from the lake. In the second draft (fr. 2) there is only a description of the magic of spring time; the persona of alafroiskiotos and the "Lady clad in the Moon" are both absent.

\section{Sikelianos" "Alafroiskiotos" and the preternatural Leucadian light}

The Leucadian Anghelos Sikelianos (1884-1951) wrote "Alafroiskiotos", his first major literary piece, in the Libyan desert in 1907, revised it on his native island, where he spent time with his bride Eva Palmer, and published it in 1909. It is a long lyrical poem of 2.293 lines. It has no plot and is divided into three major sections and sixty units bearing individual titles. In the poem Sikelianos claims the heritage of two fellow Heptanesians, the Zakynthian Dionysios Solomos and the Ithacan Odysseus, the Homeric hero. 
My concern will be mainly with the Homeric background of the poem. It is significant that at the time Sikelianos was writing "Alafroiskiotos" and revising it on his native Leukas, the German Archaeologist Wilhelm Dörpfeld was conducting excavations on Leukas and proposing an identification of the island with the Homeric Ithaca. ${ }^{25}$ In the opening units of "Alafroiskiotos" the speaking person poses as Odysseus who returns not to Ithaca but to Leukas; and later on various occasions he renews and reinterprets the role of the Homeric hero. ${ }^{\mathbf{2 6}}$

The island of Leukas is not mentioned in the Homeric epics, at least not by this name. There is only a famous reference to the Leukas petre or White Rock: it is located on the edge of the world and mentioned as a gateway to the Underworld at the moment Hermes is conducting the souls of the suitors to Hades: "Past the streams of Oceanus they went, past the White Rock, past the Gates of the Sun and the Land of Dreams, and quickly came to the meadow of asphodels, where the spirits dwell, the shades of the dead" (Odyssey 24.11-14). The Leukas petre was sometimes identified with Cape Leukatas, from which the island was believed to have received its name and which was a landmark for the passage from life to death, as in the scapegoat rite of dropping people into the sea (katapontismos) or in Sappho's legendary leap. ${ }^{\mathbf{2 7}}$

Sikelianos' Leukas is situated on the borderline between life and death, like the Leukas petre and Cape Leukatas. "Аદuкós" (leukos, lefkos) is etymologically associated with light and vision, but the light that pervades Leukas has something preternatural to it. Sikelianos nowhere mentions his island by name (only Cape Leukatas) but he constructs its image by exploiting the "brightness" of "leukos", derivatives and compounds, ${ }^{\mathbf{2 8}}$ as well as of dozens of synonyms. On Leukas everything is distilled into light: light springs from within the soul and mystic

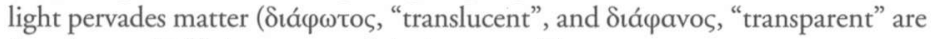
favorite words), ${ }^{29}$ the upper and the lower world.

This is all spiritual light and makes its most significant presence at and after sunset, in darkness, and during sleep - the Gates of the Sun and the land of Dreams mentioned in the Homeric passage seem to have been embedded in Sikelianos' Leucadian landscape. Sleep is invariably vigilant; the eyes remain

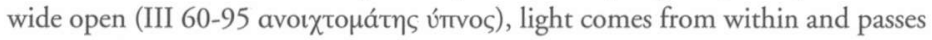
through the closed but translucent eyelids. It is in darkness and sleep that visions and revelations commonly occur, a constant reminder of the intertextual (Homeric) and supernatural character of light and vision.

On Sikelianos' Leukas the unearthly light of the Odyssean tradition coexists with the supernatural vision bestowed to Diomedes by Athena, who was also 
Odysseus' faithful divine companion. The gaze of Athena receives particular

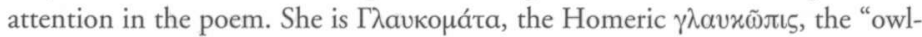
eyed" goddess. Athena, who is born at night, and the poet, who has revelatory visions after sunset or during sleep, share with the owl the wide open, vigilant eyes and an unmoving gaze that pierces the darkness. In the section entitled

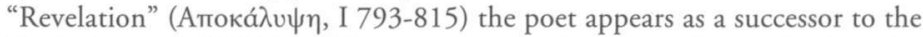
Iliadic Athena (cf. III 252-264) and tears open with his own hands the deceptive mist that veils the world, thus revealing the light behind it:

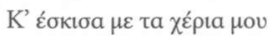

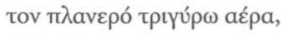

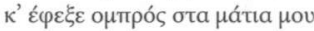

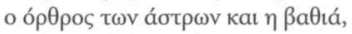

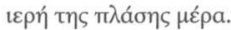

Mıa $\lambda u ́ p a$ tou aкoúүovtav

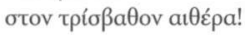

The poet, his patron goddess and the owl $(\gamma \lambda a v \xi)$ are all at home among the olive-trees of his native island. There is recurring semantic interaction of the

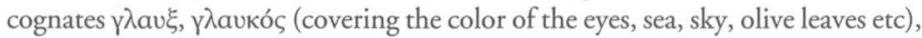

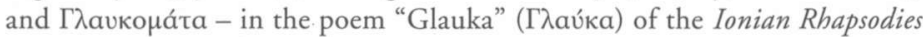

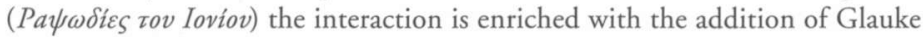
(Г $\lambda$ aúкๆ), originally the Nereid who personified the gleaming or bluish green / grey sea (Hes. Theog. 244). As a boy the poet used to lie down under the olivetrees and taste the light. Now he senses the touch of Homer and guides the blind poet on the night paths, his eyes wide open, his steps lighted by the mystic light the olive-trees emit thanks to the oil they carry inside; and with another touch by Homer he takes the path through the Leucadian olive-trees and enters the underworld, the bright meadow of asphodels (III 140-153, $421 \mathrm{ff}$ ).

Sikelianos allusively associates the term alafroiskiotos with Odysseus' words at the beginning of Sophocles' Ajax (125-126): "we living people are nothing else

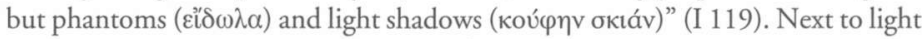
the other pervasive notion in "Alafroiskiotos" is lightness: images of soaring, rising, ascending, flying, skin-shedding recur obsessively. Words for lightness ( $a \lambda a \varphi \rho o ́ c$, compounds and derivatives) interact semantically with words for

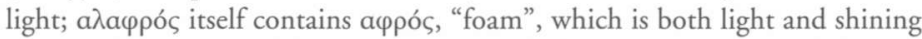
white. The poem could actually be described as a symphony in light and lightness. 
The preternatural Leucadian light envisaged by Sikelianos in "Alafroiskiotos" brings together the unearthly light of the Odyssean landscape of the dead, the superhuman vision bestowed by Iliadic Athena, the guiding vision and reason of Odyssean Athena, and the inward vision of blind Homer. Sikelianos assigns himself the double role of successor and guide to (blind) Homer and in this respect his poetic ambition rises much higher than that of Solomos in the "Shade of Homer" ${ }^{\mathbf{3 0}}$ The poet bypasses the Latin tradition (Virgil and Boethius). Though he may have known that Nikolaos Politis used also the Virgilian episode to elucidate the notion of an alafroiskiotos, Virgil's imperial and Boethius' consolatory vision fell outside the scope of the poet's program. The goal of this program was to establish "bright" Leukas as the land of revelation by virtue of its name, landscape, and literary and archaeological tradition, and himself as the son who absorbed his native island's mystic light. ${ }^{31}$

\section{$\Sigma$ H M I $\Omega \Sigma E \mid \Sigma$}

1 On the problems associated with Diomedes' supernatural vision and $\theta \varepsilon \mathrm{cou}$ -

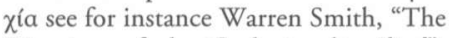
Disguises of the Gods in the Iliad", Numen 35 (1988), pp. 161-178; Ruth Scodel, "The Wits of Glaucus", Transactions and Proceedings of the American Philological Association 122 (1992), pp. 73-84; Stephen Fineberg, "Blind Rage and Eccentric Vision in Iliad 6", Transactions and Proceedings of the American Philological Association 129 (1999), pp. 13-41.

2 K. F. B. Fletcher, "Vergil's Italian Diomedes", AJP 127 (2006), pp. 219-259: 247-250.

3 For a convincing defense of the authenticity see Gian Biagio Conte, "The Helen Episode in the Second Book of the Aeneid: Structural Models and a Question of Authenticity", in: The Rhetoric of Imitation: Genre and Poetic Memory in Virgil and Other Latin Poets, Ithaca, 1986, pp. 196-208.
4 The reasons behind the imprisonment and execution of Boethius are complex and unclear; see John Moorhead, Theoderic in Italy, Oxford, 1992, pp. 219235.

$5 \mathrm{On}$ the Consolation and its reception see briefly Routledge History of Philosophy, vol. III, Medieval Philosophy, edited by John Marenbon, London / New York, 1998, pp. 11-28; and in greater detail The Cambridge Companion to Boethius, edited by John Marenbon, Cambridge, 2009, pp. 181-302; John Marenbon, Boethius, Oxford, 2003, pp. 96-182. The most recent edition is by Claudio Moreschini, Boethius, De consolatione philosophiae, opuscula theologica, Munich / Leipzig, 2000; the most recent commentary is by Joachim Gruber, Kommentar zu Boethius, De consolatione philosophiae, 2., erweiterte Auflage, Berlin / New York, 2006, and a recent English translation by J. C. Relihan, 
Boethius: Consolation of Philosophy, Indianapolis / Cambridge, 2001. For a Greek translation and introduction to Boethius

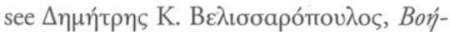

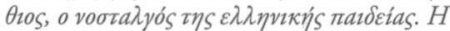

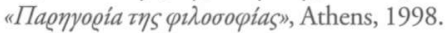

6 J. C. Relihan, Ancient Menippean Satire, Baltimore, 1993; id., The Prisoner's Philosophy: Life and Death in Boethius's Consolation, Notre Dame, 2007, on the ironic character of the work.

7 Gerard O'Daly, The Poetry of Boethius, London, 1991.

8 On light imagery and the Enlightenment see R. Mortier, "Lumière et Lumières: histoire d'une image et d'une idée au XVIIe et au XVIIIe siècle", in: R. Mortier, Clartés et ombres du siècle des Lumières,

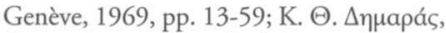

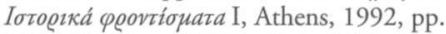

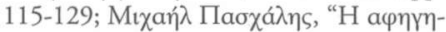
натотої

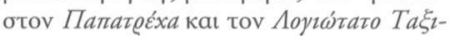

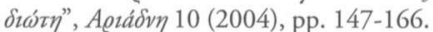

9 Edward Larrissy, The Blind and Blindness in Literature of the Romantic Period, Edinburgh, 2007.

10 See now in detail Michael Paschalis, "The History and Ideological Background of Korais' Iliad Project", in: Paschalis M. Kitromilides (ed.), Adamantios Korais and the European Enlightenment, Oxford, Voltaire Foundation, pp. 109-124.

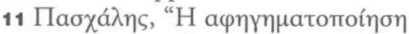

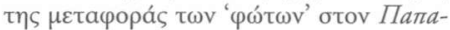

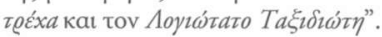

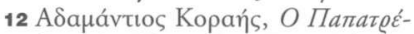
xas, edited by 'A 1970, p. 137.

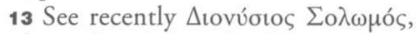

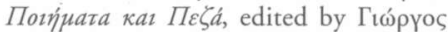

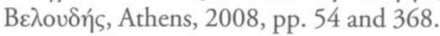

14 See among others: L. Coutelle, For- mation poétique de Solomos (1815-1833),

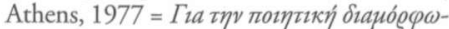

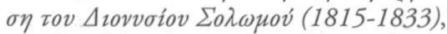

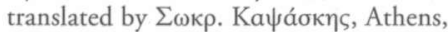
2009, pp. 223-228; David Ricks, The Shade of Homer, Cambridge, 1989, pp.

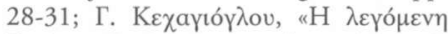

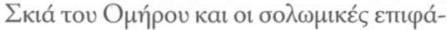

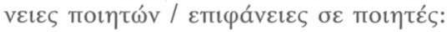

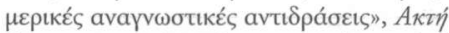

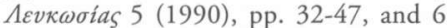
(1991), pp. 135-151; I. N. Perysinakis, "The Shade of Homer: Solomos, Petrarch, Ennius", $\Delta \omega \delta \omega ́ v \eta 10$ (1991), pp. 175-188.

15 See the previous note.

16 Modern editions of Africa follow the Latin pronunciation of Petrarch's time (toge, instead of togae).

17 Martin McLaughlin, Letizia $\mathrm{Pa}$ nizza, Peter Hainsworth, Petrarch in Britain: Interpreters, Imitators, and Translators over 700 years, Oxford, 2007, pp. 61-82.

18 For instance, G. P. Savvidis has argued that the meeting of Homer and Solomos is "as explicitly symbolic as the meeting of Virgil and Dante", adding that "it is potentially much arrogant, for one feels that it is Homer who is about to say: Tu duca, tu segnore et tu maestro"; see "The Burden of the Past and the Greek Poet from Aeschylus to the Present Day", in: $\Gamma$.

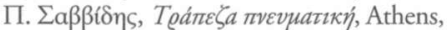
1994, pp. 148-170: 155.

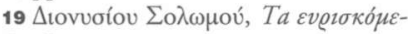
va, Corfu, 1859, p. 222.

20 9.169-9.171: Sedibus exierant oculi. Cava frontis ymago / horrorem inculta cum maiestate ferebat. / Dirigui.

21 On Solomos and Dante see now

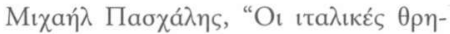

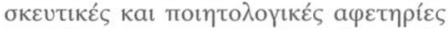

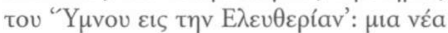

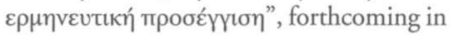




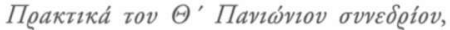
Paxoi, 26-30 May 2010.

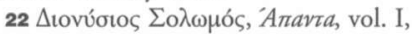
edited with notes by Linos Politis, Athens, 1993, p. 245.

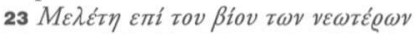

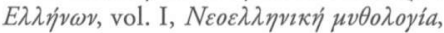
Athens, 1871 , p. 102, note 4 . The passage of Politis is pointed out in Ricks (The Shade of Homer, p. 58), but only as regards the Homeric passage.

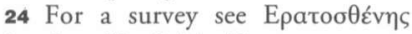

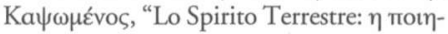

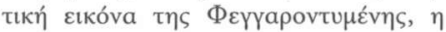

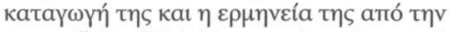

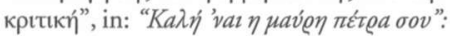

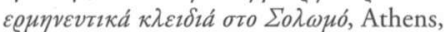
1992, pp. 203-251, 342-351.

25 Wilhelm Dörpfeld, Leukas: zwei Aufsätze über das homerische Ithaka, Athens, 1905 (reprints of publications of 1902 and 1904). On Homer and "Alafroiskiotos" see Ricks, The Shade of Homer, pp. 57-64; on "Alafroiskiotos", Solomos

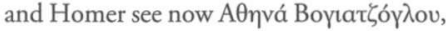

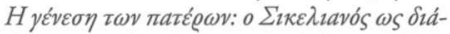

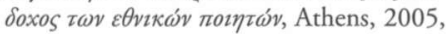
pp. 19-44, with a survey of secondary literature.

26 The discussion of Odysseus in "Ala-

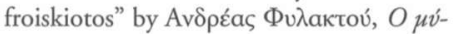

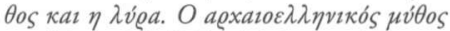

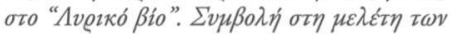

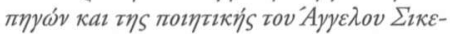

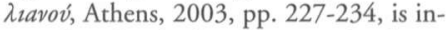
complete: he singles out a couple of passages whereas Odysseus is subtly present in a lot more.

27 Gregory Nagy, "Phaethon, Sappho's Phaon, and the White Rock of Leu- kas", Harvard Studies in Classical Philology 77 (1973), pp. 137-177; J. D. Morgan,

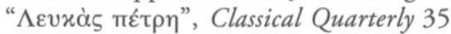
(1985), pp. 229-243; Michael Paschalis, "Virgil's Actium-Nicopolis", Proceedings of the 1st International Symposium on $\mathrm{Ni}$ copolis, Preveza, 1987, pp. 57-68.

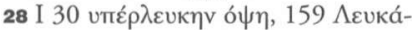

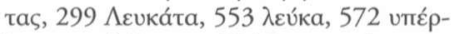

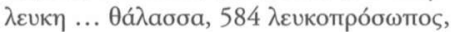

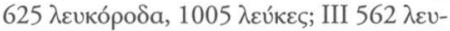

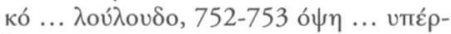
$\lambda \varepsilon \cup \kappa \eta$.

29 I 20, 637, 674, 887; II 11, 27; III $68,644,668,694$

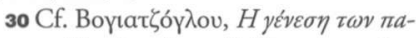

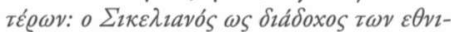

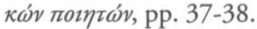

31 Cf. the opening of the chapter "Lefkas", a commentary on "Alafroiskiotos", in: Eva Palmer Sikelianos, Upward Panic, edited with an introduction by John Anton, Harwood Academic Publishers, 1993, p. 67: "The return. For him to his home: which was at once the outward aspect of this shining Ionian mountain rising out of the sea, and the vision, the feeling, the knowledge (they are one) of this sun within, which made his flesh transparent". On revelation in "Alafroiskiotos" see further Nektaria Klapaki, Versions of the Modern Literary Epiphany in Twentieth-Century Greek Poetry: Cavafy, Sikelianos, Seferis, Embirikos, Ph.D. thesis, King's College, London, 2005, pp. 140168. I would like to thank A $\theta$ үrá Boyıa$\tau \zeta$ óp bibliographical references concerning Sikelianos. 


\section{П E P I A H $\boldsymbol{\Psi}$ H}

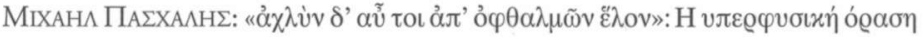

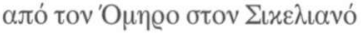

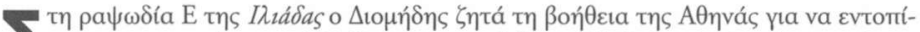

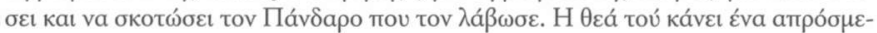

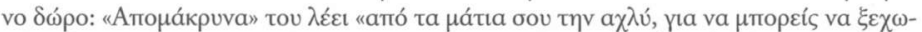

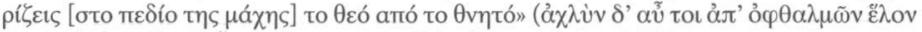

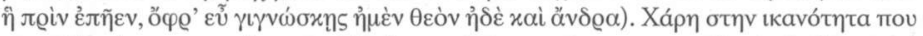

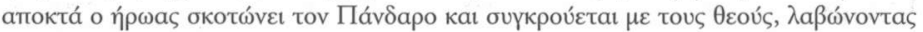

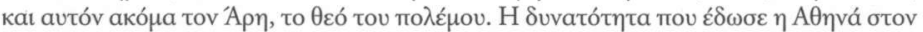

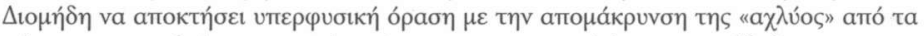

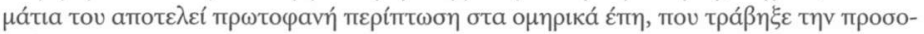

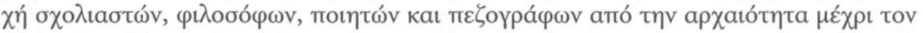

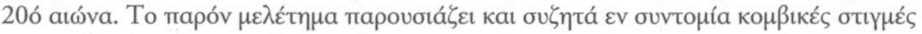

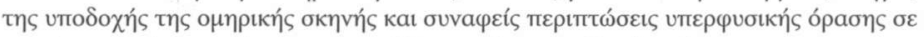

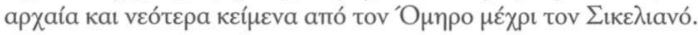

